\title{
From Rio to Rwanda: Impacts of the IMFN over the past 20 years
}

\author{
by Brian Bonnell ${ }^{1}$, Ronnie de Camino 2 , Chimère Diaw ${ }^{3}$, Mark Johnston $^{4}$, \\ Przemyslaw Majewskí ${ }^{5}$, Isabelo Montejo ${ }^{6}$, Miguel Segur ${ }^{7}$ and Johan Svensson ${ }^{8}$
}

\begin{abstract}
2012 represents the $20^{\text {th }}$ anniversary of the Model Forest concept and the International Model Forest Network (IMFN). Since it was announced at UNCED in 1992, the network has grown to almost 60 Model Forests in 25 countries covering over 100 million hectares. Model Forests have been involved in a wide range of activities in support of sustainable natural resource management. In this paper, we will provide an overview of the context within which the Model Forest concept emerged in the early 1990s, describe the Model Forest approach and the IMFN, highlight the evolution of the regional Model Forest networks, and provide a few examples of the impacts of the IMFN and Model Forests over the past 20 years.
\end{abstract}

Key words: Model Forest, SFM, landscape, sustainable development

\section{RÉSUMÉ}

En 2012, on fêtera les 20 années dexistence du concept de Forêts Modèle et du Réseau international de Forêt Modèles (RIFM). Depuis l'annonce de sa création, faite en 1992 lors de la Conférence des Nations Unies sur lenvironnement et le développement (CNUCED), le Réseau sest étendu et compte maintenant près de 60 Forêts Modèles, réparties entre 25 pays et occupant plus de 100 millions d'hectares. Les Forêts Modèles servent à une vaste gamme d'activités appuyant la gestion durable des ressources naturelles. Dans le présent article, nous présentons le contexte qui a vu naitre le concept de forêt modèle au début des années 1990, nous décrivons le RIFM et la démarche qui le sous-tend, nous suivons lévolution des réseaux régionaux de Forêts Modèles, et nous donnons quelques exemples des retombées quont eues le RIFM et les Forêts Modèles au cours de 20 dernières années.

Mots clés : Forêt Modèle, aménagement durable des forêts, paysage, développement durable

\section{Introduction}

With the emergence of sustainable forest management (SFM) came increased complexity in natural resource management through incorporation of a wide range of forest and landscape stakeholder interests well beyond timber. Model Forests were established to help bridge the gap between SFM theory and practice to explore mechanisms to translate principles of sustainable development into on-the-ground actions (Hall and Bonnell 2004). Model Forests and SFM emerged during a time of accelerated global environmental concern, change and policy-making, globalization of natural resource markets, and increasing public demand for participation in resource management. Model Forests focus on implementation, evaluating existing knowledge and involving a broad range of stakeholders to examine issues of sustainability on a land- scape scale. The Model Forest approach encompasses multistakeholder collaborative processes and effective mechanisms for conflict resolution required for the achievement of SFM.

\section{A Global to Local Foundation}

Several factors and circumstances came together in the late 1980s and early 1990s facilitating the emergence of the Model Forest concept. At the time, a series of global programs was indicative of a change towards larger-scale and more integrative perspectives on environmental issues (Brown et al. 1987). The most prominent was the UN World Commission on Environment and Development (the Brundtland Commission) which released its report, Our Common Future, in 1987. This laid the foundation for the 1992 UN Conference on the Environment and Development (UNCED) held in Rio de

\footnotetext{
${ }^{1}$ Senior Program Specialist, International Model Forest Network Secretariat, Natural Resources Canada - Canadian Forest Service, 580 Booth Street, Ottawa, Ontario K1A 0E4. E-mail: bbonnell@nrcan.gc.ca

${ }^{2}$ President, Ibero-American Model Forest Network; Deputy Director General, CATIE, Turrialba, Costa Rica.

${ }^{3}$ Director General, African Model Forest Network Secretariat, Yaoundé, Cameroun.

${ }^{4}$ Vice-President for Science and Research, Canadian Model Forest Network; Senior Research Scientist, Saskatchewan Research Council, Saskatoon, Saskatchewan.

${ }^{5}$ Director, Silver Taiga Foundation and Komi Model Forest, Syktyvkar, Russia.

${ }^{6}$ Regional Technical Director, Region VII, Forest Management Bureau, Department of Environment and Natural Resources, Cebu, Philippines; IMFN Networking Committee - Asia.

${ }^{7}$ Regional Coordinator, Mediterranean Model Forest Network; Head, International Cooperation Area, Cesefor, Valladolid, Spain.

${ }^{8}$ Director, National Inventory of Landscapes in Sweden, Swedish University of Agricultural Sciences, Umeå, Sweden; IMFN Networking Committee - Northern Europe.
} 
Janeiro, Brazil. In addition, the whole concept of sustainable development that emerged was ambiguous, which led to its use by a broad spectrum of individuals and organizations (Dixon and Fallon 1989), sometimes with diverging directions. This created a need translate the principles inherent in the concept into practice.

Also during that time, the public was demanding more say in environmental governance, particularly related to forest management. This was clearly illustrated through the increasing number of major demonstrations against forest practices taking place around the world-e.g., protester arrests in Clayoquot Sound, Canada (Ceric 2009) and the Njakafjäll conflict in Sweden (Lisberg-Jensen 2002). All of this was leading towards a paradigm shift in forest management away from sustained yield towards a more social approach to management (Kimmins 1995) where a balance between ecological, social, cultural and economic goals and values had to be considered.

\section{Model Forests and the IMFN}

Model Forests were developed as part of the Partners in Sustainable Development of Forests Program under Canada's Green Plan. The goal of the Program was to shift the management of forests from sustained yield to sustainable development (Forestry Canada 1991). To address that challenge, an entirely new approach had to be taken, to not just change practices, but also attitudes. This meant moving forward in three key areas: 1) examining issues at a large scale and across jurisdictional boundaries, 2) encouraging a diverse group of people and organizations to discuss issues, and 3) incorporating the principles of sustainable development into the discussions. It is these three concepts-landscapes, partnerships, sustainability - that formed the foundation of Model Forests (LaPierre 2002, Hall and Bonnell 2004). In addition, the implementation of the Model Forest approach relies on a bottom-up approach to SFM by addressing problems and needs that are local by nature and make sense in practice (Besseau et al. 2002). Such local anchorage is needed to advance SFM (Rametsteiner 2009).

While there were numerous examples from around the world of partnership-based approaches to natural resource management (Mayers and Vermeulen 2002), these were mainly limited to government-community or community-industry type partnerships. The Model Forest concept expanded greatly on the partnership-based approach and required a wide range of stakeholders to be involved (Hall and Bonnell 2004). Within each Model Forest, participating stakeholders develop a governance structure that facilitates the active participation and decision-making of interested stakeholders (IMFN Secretariat 2008). Importantly, the character of each Model Forest is a function of local conditions, including who is present, who is interested in participating and available, and local issues. Elbakidze et al. (2012, this issue) explore the importance of stakeholder analysis in adaptive governance using the Kovdozersky Model Forest (Russia) as a case study.

\section{International Model Forest Network}

The Model Forest concept was first brought to the world's attention at UNCED in 1992 where Canada promised to "internationalize" its innovative Model Forest Program. By 1994, three sites had been developed outside of Canada - two in Mexico and one in Russia-and the IMFN was established
(Besseau et al. 2002). The IMFN has since grown to encompass 60 sites in 30 countries (Fig. 1), a substantial increase since the September/October 2002 issue of The Forestry Chronicle celebrated 10 years of Model Forests.

Early development of Model Forests outside of Canada was based on "twinning" relationships with an established Model Forest in Canada and a site in another country (Besseau et al. 2002). For example, the Eastern Ontario Model Forest (Canada) was twinned with Calakmul in Mexico, Foothills with Chihuahua (Mexico) and McGregor (now Resources North) with Gassinski (Russia). In some instances, informal twinning relationships emerged such as the one between the Manitoba Model Forest (Canada) and Mariposa Monarca (Mexico).

In response to growing global interest, an IMFN Secretariat was established in 1995 at Canada's International Development Research Centre (IDRC). After 12 years at IDRC, the IMFN Secretariat moved to Natural Resources Canada Canadian Forest Service (NRCan-CFS) in Ottawa where it is now housed.

\section{Regional Model Forest Networks}

While the IMFN is overseen by the secretariat based in Canada, a number of semi-autonomous regional Model Forest networks have emerged, including: Canadian Model Forest Network (CMFN), Ibero-American Model Forest Network (IAMFN), Mediterranean Model Forest Network (MedNet), African Model Forest Network (AMFN) and the Regional Model Forest Network - Asia (RMFN-Asia). A regional network in the Baltic region of northern Europe and northwestern Russia is also starting to emerge. Regional networks were created to facilitate Model Forest development and programming reflecting the priorities, strengths and opportunities unique to a particular region. Each regional network has established its own governance structure.

\section{Regional Overviews \\ Africa}

Central Africa contains the second largest continuous block of rainforest after the Amazon Basin with almost 258 million ha of forest cover (de Wasseige 2009). Model Forest development in Africa was initiated in Cameroon in 2003 by the Center for International Forestry Research (CIFOR) and its partners in collaboration with the IMFN Secretariat (Jum et al. 2007). The idea to develop Model Forests in the region arose out of CIFOR's adaptive collaborative management experiences in Cameroon (Diaw et al. 2009). After two years of working with Cameroon's forest administration, local partners and international agencies-including the Canadian International Development Agency (CIDA), the Central African Forest Commission, IUCN and FAO-two Model Forests in Cameroon were identified, Campo Ma'an and Dja et Mpomo.

In 2008, a regional secretariat for the emerging African network was established in Yaoundé, Cameroon and, in 2009, Canada launched the African Model Forest Initiative. The initiative aims to improve the conservation and sustainable management of forest resources in francophone Africa, including the Congo Basin and Mediterranean regions. Current activities focus on climate change and Model Forest expansion into the Democratic Republic of the Congo and elsewhere. 


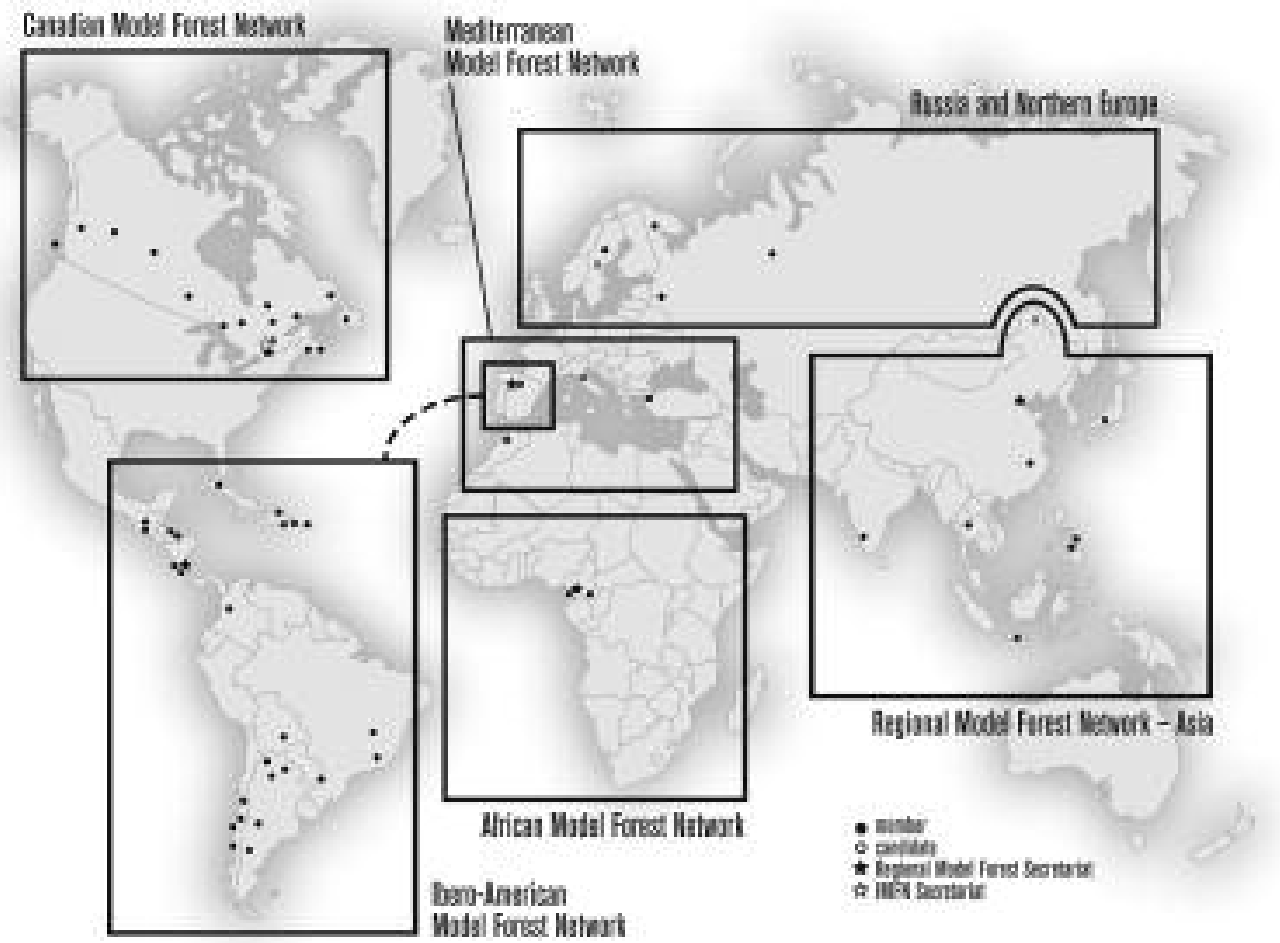

Fig. 1. International Model Forest Network

\section{Asia}

Asia is home to 4.1 billion people, more than 60 percent of the global population (UNDESA 2012). It is estimated that approximately 400 million people live in rural areas, close to forests and are predominantly classified as poor (EC and UNDP 2002). As these people have little access to opportunities for development, forests often provide all or a significant portion of their livelihoods. As such, a reduction in forest degradation is generally dependent upon social and economic development that provides alternative income generation opportunities.

Model Forest development in Asia began in China in 1996 when the concept was included in a memorandum on forestry cooperation between China and Canada. In 1997, the Lin'an Model Forest in Zhejiang Province was launched. However, it was not until 2000 that Model Forest development in Asia really moved forward and a regional network began to emerge. Building on the IMFN workshops hosted by the Forestry Agency of Japan between 1998 and 2000, the Government of Japan funded a Regional Model Forest Project from 2000 to 2003. A secretariat was established at the FAO Regional Office for Asia and the Pacific in Bangkok and covered four countries: China, Myanmar, Philippines and Thailand. Supported first by the regional project and then by the IMFN Secretariat, a series of regional workshops was held between 2000 and 2004 that focused on criteria and indicators, bamboo and hickory nut production, forest policy, monitoring and evaluation, strategic planning, and resource mobilization.

Between 2003 and 2007, funding was provided for siteand regional-level activities by the IMFN Secretariat and sub- sequently by the Canadian Model Forest Network through the IDRC-sponsored project, Enhancing the Action Research Capacity of the IMFN. An office for the RMFN-Asia was opened in 2010 and is hosted by the Chinese Academy of Forestry in Beijing. Key themes for the region include community sustainability, climate change, ecological goods and services, and good governance.

\section{Canada}

The forests and wooded land of Canada cover 397.3 million hectares representing $10 \%$ of the world's forest cover and $30 \%$ of the world's boreal forest (NRCan 2011). After a competitive process in which 50 proposals were reviewed by a National Advisory Committee on Model Forests established by the Minister of Forestry, an initial network of 10 sites was supported in Canada. Even though it was originally funded as a five-year initiative, Canada's Model Forest Program eventually covered three, five-year phases: 1992-97, 1997-2002, and 2002-07. Although the Program ended in 2007, many Model Forest activities continued to be supported through the Forest Communities Program, which focused more on economic development opportunities for local communities than SFM.

Phase I (1992-97) can very much be characterized by a focus on the local partnerships, the development of effective ground rules and frameworks, the enhancement of knowledge of local conditions, and building a commitment to work together towards a common goal. Research activities accounted for $60 \%$ of Model Forest programming during the initial five years (NRCan 2006). Bonnell (2012, this issue) provides an overview of research trends in the Canadian Model Forests. 
After a strong emphasis on partnership-building and research during the first five years, Phase II (1997-2002) of the Program focused on the sharing of experiences and demonstrating innovations. During this time, several strategic initiatives were introduced to enhance network-level participation in issues relevant to all Model Forests, including local-level indicators and aboriginal involvement.

There was a significant increase in the development of SFM systems and tools in Model Forests during Phase III (2002-07). Guides to help forest managers integrate biodiversity conservation and natural disturbance-based practices into their work were developed and shared (e.g., Ehnes and Sidders 2001, Betts and Forbes 2005, Thorpe et al. 2007), as well as best management practices for small woodlot owners (EOMF 1996, Fortin et al. 2002, Nova Forest Alliance 2002). Network-level strategic initiatives continued during Phase III with the themes expanded to include climate change and private woodlots.

In 2007, after 15 years, Canada's Model Forest Program ended and NRCan-CFS initiated the Forest Communities Program. The new program was designed to assist communities in developing and sharing knowledge, strategies and tools to adjust to the transitions taking place in the forest sector by taking advantage of emerging forest-based opportunities. The programming change affected not just the themes being focused on but also the number of Model Forests. Several new sites were added to the CMFN and the Bas-Saint-Laurent Model Forest closed.

During this transition, the CMFN also became an independent, not-for-profit organization moving away from a government-based secretariat. The CMFN has a board of directors and the member sites are shareholders of the new corporation. The current network governance structure includes a number of vice-presidents whose responsibilities include science and research, international programs, communications, business development, policy and partnerships, member services and finance.

\section{Ibero-America}

Latin America contains the greatest biological diversity in the world holding half of the world's tropical forests (UNEP 2010). The region, including Mexico, contains 950 million ha of forests (FAO 2010) and has both the largest unfragmented tropical forests (Amazon) and some of the most fragmented and endangered ones (UNEP 2010). Although it has slowed somewhat, the rate of deforestation is the second-highest in the world (FAO 2010).

In 1998, the first Model Forest in Latin America was established in Chile and, in that same year, Argentina committed to develop Model Forests in each of its major forest regions. Rapid growth of Model Forests and growing interest in the concept led to the development of the IMFN's first regional network. Originally known as the Regional Model Forest Network for Latin American and the Caribbean with a secretariat based in Chile, the regional team moved to the Tropical Agricultural Research and Higher Education Center (CATIE) in Costa Rica in 2004. With the involvement of the Urbión Model Forest (Spain), the network changed its name to the Ibero-American Model Forest Network.

Today, the IAMFN is the largest regional network in the IMFN with 26 Model Forests in 14 countries. The regional network experienced significant growth between 2004 and
2010 when the number of Model Forests more than tripled from seven to 25 . The IAMFN is governed by a board of directors consisting of one representative from each member country (as appointed by the government institution that is signatory to the network), one Model Forest representative per member country regardless of the number of Model Forests in a country, and one representative from each partner institutions, including CATIE, CUSO International, FAO and the IMFN Secretariat (Landry et al. 2011).

While a key role of the IAMFN secretariat is the strengthening and supporting of individual Model Forests in the region, including the sharing of best practices, there is an increasing focus on regional-level activities and the development of links with other organizations. The IAMFN secretariat has facilitated implementation of regional projects on analog forestry, knowledge management, community sustainability, climate change, and, more recently leadership for sustainable development.

\section{Mediterranean}

The forests of the Mediterranean region are generally characterized by an exceptionally large variation in environmental conditions with a huge diversity of plants and animals with high genetic variability (FAO 2012). Mediterranean forests have also evolved with successive civilizations over thousands of years (M'Hirit 1999) that have transformed and shaped the landscape and its ecosystems with use.

The Urbión Model Forest was established in 2007 in Spain's Castile and Leon region. Although the Model Forest is involved with the IAMFN, there was an early vision to develop Model Forests throughout the Mediterranean basin. Since the establishment of the Mediterranean Model Forest Network and its secretariat (commissioned by the Regional Government of Castile and Leon to the Cesefor Foundation) in 2008, two new Model Forests-Ifrane (Morocco) and Yalova (Turkey) - and one candidate-Montagna Fiorentina (Toscana, Italy)-have been accepted as members of the IMFN. Several more are in advanced stages of development (in Algeria, Croatia, France, Italy, Spain, and Tunisia) with a dozen other regions and countries beginning the development process.

The European Union's INTERREG "Forêt Modèle" project, which finished in March 2012, provided opportunities to consolidate Model Forest processes in several territories and to initiate strategic projects based on common regional priorities. A key challenge in the Mediterranean region has been the number of languages spoken and the regional Web site provides materials in many languages, including Arabic, Croatian, English, French, Greek, Italian, Spanish, and Turkish. In addition to traditional print media and video, the region is making use of Web 2.0 technologies such as Facebook and Twitter (twitter.com/\#!/medmodelforest) to deliver key messages.

Current regional priorities include traceability of timber and non-timber forest products, an analysis of capabilities and opportunities in the field of ecotourism under a common framework, and the implementation of webGIS capabilities in the region's Model Forests.

\section{Europe and Russia}

The forests of Europe cover 195.9 million ha, with Russia containing an additional 809 million ha (FAO 2010). Forestry 
activity provides over 1.3 million jobs in both Europe and Russia (FAO 2010) and non-wood forest products and services are an important source of income in many areas (MCPFE 2003). However, there has been a significant downward trend in forest-based employment since the 1990s (MCPFE 2003, FAO 2010).

Russia was the second international partner in the IMFN when the Gassinski Model Forest was established in the far eastern territory of Khabarovsk Krai in 1994. Initial development of the Model Forest was supported by Canada through a twinning relationship with Canada's McGregor Model Forest $^{9}$. After 16 years of successful programming in conservation, indigenous peoples' engagement in the forest sector and local economic development, the Gassinski Model Forest officially closed in 2010 .

Additional sites have also been established in western Russia, including Kovdozersky in 2005 and Komi and Pskov in 2006. Also in 2006, the Model Forests began meeting with Russia's Federal Forest Agency and the Saint Petersburg Institute of Forest Research (SPbNIILH) to discuss forming a national Model Forest network. Although a national network has not fully formed in Russia, the Komi Model Forest has taken the lead on coordinating activities and information exchanges between the sites.

The process of establishing the Vilhelmina Model Forest (Sweden) in 2004 (Svensson et al. 2004) as the first site in Europe generated a need to review and evaluate the current Swedish and northern European approach to, and capacity for, strategic and operational landscape-level and multiobjective planning and governance. This formed the background for the 2006-07 Baltic Forest INTERREG (EU INTERREG) project. The project explored the incentives for introducing the Model Forest concept on top of already existing landscape-level initiatives in northern Europe.

The follow-up 2012-14 Baltic Landscape INTERREG project (Baltic landscape in change - innovative approaches toward sustainable forest landscapes) was developed by the Swedish University of Agricultural Sciences in close cooperation with the Swedish Forest Agency and other organizations. The new project includes 14 partner organizations from Sweden, Finland, Poland, Belarus, Latvia, Estonia and Norway with connections also being maintained with Model Forests in northwest Russia. The goal is to implement the Model Forest concept and to develop locally relevant landscape-level approaches to sustainability within the context of national and pan-national policies and framework-for example the Swedish Environmental Quality Objectives, the European Landscape Convention and the European Union Water Framework Directive. In total, seven landscapes-three in Sweden including the Vilhelmina Model Forest, two in Poland and one each in Finland and Belarus-have been identified.

\section{Key Impact Areas and Activities IMFN global fora}

Members of the IMFN have periodically gathered together to exchange ideas and examine opportunities and options for future Model Forest and network development. Early meet-

\footnotetext{
${ }^{9}$ The McGregor Model Forest is now known as the Resources North Association.
}

ings (1993-1995) took place in Canada where delegates from Malaysia, Mexico, and Russia participated in CMFN meetings. In October 1996, the first international "Model Forest Forum" was held in the Chihuahua Model Forest (Mexico), and included participants from Canada, Indonesia, Japan, Mexico, Russia, and USA.

The next Model Forest Forum was held in Halifax, Canada in 1999 following an International Conference on Sustainable Development. At the Forum, representatives from Argentina, Cameroon, Canada, Chile, China, CIFOR, FAO, Japan, Mexico, Russia, USA and others participated in discussions on networking. The next Network forum did not take place until 2005 on the $10^{\text {th }}$ anniversary of the IMFN Secretariat. The 2005 event was held in Costa Rica and drew 110 Model Forest representatives from around the world, as well as various institutional partners. During the 2008 IMFN Global Forum in Hinton, Canada, the 150 delegates from 31 countries provided input on the strategic directions, vision and goals of the IMFN.

Over 200 delegates from 32 countries participated in the 2011 IMFN Global Forum held in Burgos, Spain. In addition to a discussion on a draft IMFN Charter, designed to formalize many IMFN procedures such as membership, the Strategic Initiative themes identified in 2008 were reaffirmed: climate change, ecological goods and services, and community sustainability. The event was preceded by the International Symposium on Ecosystem and Landscape-level Approaches to Sustainability. With FAO, CIFOR, IUCN and the Secretariat for the Convention on Biological Diversity as co-organizers, the Symposium helped place the IMFN on the international policy stage.

\section{Developing a SFM toolbox}

Model Forest activities have led to a greater understanding of ecological processes, the impacts of human and natural disturbances on forest ecosystems and the socio-economic dimensions of SFM. Various guides, models, systems and other tools have been developed and tested to assist managers, communities and others in advancing the sustainable management and use of natural resources. The guides and tools in the Model Forest "toolbox" have been adopted by forest managers, researchers, local communities and others to assist them in overcoming their challenges in managing natural resources sustainably.

Early research, testing and demonstration in the CMFN led to tools that could help managers modify harvesting operations to protect biodiversity, promote natural regeneration, minimize soil disturbance and protect water quality. Other tools developed in Canada and elsewhere focused on improving resource management planning, enhancing species-atrisk conservation, reducing risks from wildfires, using traditional ecological knowledge and measuring forest community sustainability.

Socio-economic research in the Lake Abitibi Model Forest (Canada) led to the development of a Regional Community Constellation Impact Model (RCCIM), which expanded the economic modeling process of earlier models beyond the forest sector and has been used for various community planning initiatives in the region.

Many of the activities of the Model Forests in Canada, including promoting public participation in the planning process and the development of local criteria and indicator 
(C\&I) frameworks, have facilitated the forest certification process across the country. The Eastern Ontario and BasSaint-Laurent Model Forests were instrumental in exploring how certification standards and procedures could be applied to small, private forest lands. As well, through the efforts of the Eastern Ontario Model Forest, the first non-timber forest product (maple syrup) to be identified and marketed as coming from a certified forest was achieved. In Russia, both the Komi and Pskov Model Forests facilitated large-scale forest certification in their respective regions.

A number of Model Forests have also explored alternative resource management planning processes. For example, the Prince Albert Model Forest (Canada) developed an integrated resource management plan that covered several administrative management units and was based on a comprehensive public consultation processes and an examination of a range of values other than timber. The process was documented and has led to changes in management planning in the Province of Saskatchewan. In the Philippines, the Ulot Watershed Model Forest tested a watershed-level planning process, and the Carood Watershed Model Forest has adopted a ridge-toreef planning framework encompassing both upland areas and mangroves. The Vilhelmina Model Forest (Sweden) is exploring approaches to sustainable landscape planning based on remaining natural forests in the region (Svensson et al. 2012, this issue).

\section{Local-level indicators}

C\&I frameworks are tools that have been used to define, measure and report on progress towards SFM. From 1997-2002, each Model Forest in Canada was required to develop a C\&I framework based on national criteria with locally relevant indicators defined collaboratively by stakeholders. The Canadian Model Forest C\&I experiences were documented in the User's guide to local level indicators of sustainable forest management published in 2000 (von Mirbach 2000). These experiences were also shared internationally with Model Forests in Latin America and Asia. For example, the Ulot Watershed Model Forest (Philippines) used the CMFN C\&I experience to expand on a community-level initiative of the Philippines Natural Resources Management Program called Environmental Performance Monitoring. After piloting a local C\&I approach in the Model Forest, the program was promoted throughout the country.

\section{Community sustainability}

The implementation of SFM strategies enhances forest-based economic, social and environmental benefits by, in part, improving the livelihoods of forest-dependent populations, particularly in developing nations (Angelsen and Wunder 2003). Most Model Forests are or have been involved in economic activities that support communities, livelihoods and reduce poverty, including promoting eco-cultural tourism, cultivation and marketing of non-timber forest products (NTFPs), bioenergy and certification of forest products. For example, the Komi Model Forest, located in northern Russia, conducted socio-economic research of NTFP importance for the survival of populations in remote villages. A 2009 report by the Centre for Non-Timber Resources (CNTR) highlighted the wide range of activities undertaken by Canadian Model Forests over a 15-year period, including conducting workshops, developing a woodlot-focused inventory system for NTFPs, developing online directories, and land use studies for indigenous communities (Mitchell 2009).

In addition to identifying opportunities for communities and people to get involved in NTFPs, Model Forests have been supporting improved marketing capacity. Several Model Forests in eastern Canada cooperated to produce From our Atlantic Woods, a NTFP directory, and the Fundy Model Forest created $A$ photo guide to non-timber forest products. The IMFN Secretariat is supporting the development of an online e-directory of Model Forest-based small and medium-sized enterprises that promote the sustainable use of natural resources. The project was piloted in a few Model Forests in the IAMFN and Asia regions but will be expanded in the coming years. As well, the Clayoquot Forest Communities Program is supporting the development of an online forest product traceability initiative. Mediterranean and African Model Forests have expressed interest in this initiative.

The bamboo industry is an economic pillar within the Lin'an Model Forest (China). With more than 30000 households growing bamboo, the region is the largest food bamboo producer in southern China. The Model Forest worked with the Linan Handicapped Association to provide training to disabled farmers to ensure they were included in the economic opportunities being developed. Research into improved bamboo production techniques that relied on less fertilizers and pesticides was also supported to improve the quality of products.

Since 2007, and with funding from the Canadian International Development Agency, the Brokenhead Ojibway Nation and the Manitoba Model Forest (Canada) have been cooperating with the Cabécar communities within the Reventazón Model Forest (Costa Rica) to enhance their capacity to become involved in ethno-eco-tourism. Training and education of Cabécar youth and women is also included in order to provide future project leadership.

The issue of wood residues left over from logging operations in the Congo Basin is enormous. With training and support from Lac-Saint-Jean Model Forest (Canada), and funding from the Canadian government, the Dja \& Mpomo Model Forest (Cameroon) has been experimenting with ways to create value out of exotic wood scraps otherwise left to decay. One such example is the production of wooden pens that have generated thousands of dollars in sales that were reinvested in the business including development of new wood residue products.

\section{Engagement of indigenous peoples, women and youth}

With both traditional and contemporary forest experiences, indigenous peoples are well positioned to contribute to today's SFM practices for the benefit of their communities and others. Indeed, Model Forest stakeholders recognize that without the involvement of indigenous partners the sustainable development of forest-dependent communities is unlikely to occur. Over 20 Model Forests include active indigenous participation in areas such as representation on the Board of Directors-e.g., Araucarias del Alto Malleco Model Forest (Chile) and the Prince Albert Model Forest (Canada).

The Campo Maan Model Forest has helped foster female entrepreneurship in Southeast Cameroon (Tiani et al. 2012, this issue). With a dedicated place in the Model Forest governance process, the women's platform of Campo Maan Model 
Forest ensures their participation in decision-making and the realization of opportunities to take concrete steps to promote social, cultural and economic development in their communities.

Beginning in 2003 when representatives from the Prince Albert Model Forest (Canada) and the Vilhelmina Model Forest (Sweden) met at the World Forestry Congress, the two sites have been sharing knowledge and experiences on SFM and aboriginal issues in particular. The relationship led to a series of exchanges between Cree and Sámi youth. In 2011, the relationship between the two Model Forests was expanded through a trilateral agreement to include the Araucarias del Alto Malleco Model Forest (Chile). Also within the Vilhelmina Model Forest (Sweden), Sámi people maintain traditional reindeer husbandry alongside industrial forestry, and other land use, on both public and privately owned land. The Model Forest was used as a platform to explore the potential of using participatory GIS (pGIS) as a tool for collaborative learning on resource management (Sandström et al. 2012, this issue).

\section{Biodiversity conservation}

Forests are the most biologically diverse land-based ecosystem and biodiversity represents the foundation for the health and vitality of forests and ecosystem services people rely on (CBD Secretariat 2010). Most Model Forests are biologically diverse, and often include landscape areas with significant conservation or preservation values, such as national parks and world heritage forests containing species at risk. By promoting a landscape-level approach, Model Forests foster a reduction in forest fragmentation (Svensson et al. 2012, this issue), enhance wildlife habitat and support the development of collaborative strategies with local communities for managing biodiversity.

In conjunction with local stakeholders, the Kodagu Model Forest (India) helped revive many of the 1214 sacred grove sites (Devarakadu) that were losing their physical, social, cultural and religious significance. Although relatively small in physical size-varying from 0.5 ha to 300 ha-their distribution throughout the landscape has ensured that they conserve a significant proportion of biodiversity of Kodagu (Kushalappa and Raghavendra 2012, this issue).

On a different scale, the Komi Model Forest (Russia) helped create the 730 000-ha Pechoro-Ilychsky Reserve, the largest reserve of pristine forest in Europe. Similarly, activities of the Gassinski Model Forest led to the establishment of the Anyui National Park, the first in Russia (Korchumova 2007). Inventory processes developed by the Komi and Eastern Ontario (Canada) Model Forests have also been instrumental is identifying forest areas of high conservation value. In Central America, the Reventazón Model Forest (Costa Rica) has been used as a platform to explore options to promote and strengthen two biodiversity corridors as a way of fostering integrated planning with local institutions for issues related to environmental management (Moya et al. 2012, this issue).

UNESCO's Biosphere Reserves have a very similar approach to sustainable development with a focus on large landscapes and broad stakeholder participation although their origins in conservation and SFM respectively are different (Axelsson and Angelstam 2009). There are a number of Biosphere Reserves whose boundaries overlap those of Model
Forests and both groups work cooperatively to achieve common objectives (e.g., Clayoquot Biosphere Reserve/ Clayoquot Forest Communities, Dja Biosphere Reserve/ Dja et Mpomo Model Forest, Huai Tak Teak Biosphere Reserve/Ngao Model Forest, Yungas Biosphere Reserve/Jujuy Model Forest). In some cases, the Model Forest has facilitated the establishment of a Biosphere Reserve (e.g., Eastern Ontario Model Forest/Frontenac Arch Biosphere Reserve, Fundy Model Forest/Fundy Biosphere Reserve).

\section{Climate change}

As climate has a direct influence on biological and ecological processes, forests are particularly sensitive to climate change (Williamson et al. 2009), and concern is increasing about the impacts climate change will have on forests (Lazar 2005, Lemprière et al. 2008) and the communities that depend on them.

Based on broad partnerships and a focus on large landscapes, Model Forests are well-positioned to examine a variety of aspects of climate change impacts on forests and communities. In Canada, early work related to climate change focused on carbon budget modeling for forest management planning. Although the Foothills Model Forest was the initial pilot for testing a carbon budget model for the Canadian forest sector (CBM-CFS2) at an operational level (Price et al. 1997), it was not until the Canadian Forest Service's Carbon Accounting Team worked with the CMFN over a three-year period that a fully operational-scale carbon budget model (CBM-CFS3) was developed (Kurz et al. 2002). The model is also being adapted for use in other countries (Kurz et al. 2009).

A significant component of Model Forest activities related to climate change focuses on building local capacity to engage in "Reducing Emissions from Deforestation and Forest Degradation" (REDD+) projects, as well as examining vulnerability and adaptation. Between 2003 and 2006, the CMFN hosted a series of community-level workshops across Canada that focused on creating awareness and educating local communities on the potential impacts of climate change. The workshops led to the development of Pathways to climate resilience: A guidebook for forest-based communities. The guidebook will allow these communities to conduct a selfassessment of their vulnerability to current climate and climate change, as well as determine some adaptation options.

Using experiences from Model Forests, CATIE, the host of the IAMFN secretariat, has developed a series of workshops and multi-week courses focusing on REDD+ methodologies, protected areas and climate change adaptation, and forest management and climate change. The IMFN, regional networks and Model Forests have also sponsored REDD+ workshops in the Congo Basin and Asia.

Through a carbon credit project, the Chiquitano Model Forest (Bolivia) achieved a reduction in carbon-emissions from deforestation and degradation of the Chiquitano forest. In Chile, the Araucarias del Alto Malleco Model Forest implemented a "clean development mechanism" project in indigenous communities to capture carbon through the establishment of coniferous plantations. Building on experiences from this and other work in the IAMFN, a new four-year European Union funded ecoAdapt project is starting in 2012, which will involve several Model Forests in the region in strengthening REDD+ capacities of Latin American forest managers. 


\section{Looking Forward}

The Report of the Brundtland Commission, Our Common Future, in 1987, and UNCED in 1992 signaled an unprecedented global consensus on the urgent need to find real, practical and sustainable solutions to the serious environmental challenges facing the planet. Since then, a number of global initiatives and conventions have been developed to stimulate collaboration for poverty alleviation and the sustainable use and conservation of natural resources. By providing a practical and operational platform from which to translate sustainable development objectives into action, Model Forests continue to assist in the achievement of the goals of many of these international initiatives and conventions. The work of Model Forests contributes to the Millennium Development Goals (MDG), the Convention on Biological Diversity (CBD), National Forest Programs (NFP), the UN Framework Convention on Climate Change (UNFCCC), the Global Forest Objectives of the UNFF, and the UN Convention to Combat Desertification (UNCCD).

Through its work, the IMFN is gaining increasing profile on the international stage. For example, in September 2011, the IMFN was invited to participate in the Bonn Challenge, which involved various international organizations and global leaders in promoting forest landscape restoration. As well, since the launching of the International Year of Forests in New York in February 2011, Canada is actively working with the Government of Rwanda on Model Forest development in support of that country's forest restoration initiatives (Besseau et al. 2012).

2012 marks the $20^{\text {th }}$ anniversary of Model Forests and the International Model Forest Network. The network has expanded considerably from the initial ten sites in Canada and has made a significant contribution to sustainable natural resource management, strategically as well as in practice. Model Forests have evolved and adapted to a number of emerging ideas and paradigms over the last 20 years, including integrated resource management, sustainable forest management and, more recently, the sustainable management of forest-based landscapes and natural resources.

\section{Acknowledgements}

We would like to thank Peter Besseau, Dr. Fred Pollett and Deborah Luce for comments on the manuscript.

\section{References}

Angelsen, A. and S. Wunder. 2003. Exploring the forest-poverty links: Key concepts, issues and research implications. CIFOR Occasional Paper No. 40. CIFOR, Bogor.

Axelsson, R. and P. Angelstam. 2009. Landscape approach for sustainable development and sustainability: An exploratory study of Biosphere Reserves and Model Forests. Swedish University of Agricultural Sciences, Skinnskatteberg, Sweden.

Besseau, P., K. Dansou and F. Johnson. 2002. The International Model Forest Network (IMFN): Elements of success. The Forestry Chronicle 78(5): 648-654.

Besseau, P., C. Mooney, R. Verbisky, V. Mai Hô and N. DuvalMace. 2012. Changing perspectives on forests through broad stakeholder engagement: The Model Forest approach. In M. Witthaus, S. Ballard, and T. Ibgleton (eds.). Forests for people. pp. 166-170. Tudor Rose, Leicester, UK.

Betts, M. and G. Forbes. (eds.). 2005. Forest management guidelines to protect native biodiversity in the greater Fundy ecosystem, second edition. University of New Brunswick, Fredericton, NB.
Bonnell, B. 2012. Trends in research and collaboration in the Canadian Model Forest Network, 1993-2010. The Forestry Chronicle 88(3): 274-282.

Brown, B., M. Hanson, D. Liverman and R. Merideth. 1987. Global sustainability: Toward definition. Environmental Management 11(6): 713-719.

CBD Secretariat. 2010. Forest biodiversity: Earth's living treasure. Montreal.

Ceric, I. 2009. Clayoquot Sound. In I. Ness. (ed.). The international encyclopaedia of revolution and protest. Blackwell Reference Online 2009: 785-786. Available from http://yorku.academia.edu/IrinaCeric/Papers/890999/Clayoquot_Sound.

de Wasseige, C., D. Devers, P. de Marcken, R. Eba'a Atyi, R. Nasi and Ph. Mayaux. 2009. The Forests of the Congo Basin - State of the Forest 2008. Publications Office of the EU, Luxembourg.

Diaw, M.C., T. Aseh and R. Prabhu. 2009. In search of common ground: Adaptive collaborative management in Cameroon. CIFOR, Bogor.

Dixon, J.A. and L.A. Fallon. 1989. The concept of sustainability: Origins, extensions, and usefulness for policy. Society and Natural Resources 2: 73-84.

Eastern Ontario Model Forest. 1996. Code of forestry practice. Kemptville, ON.

Ehnes, J. and D. Sidders. 2001. A guide to harvesting practices to regenerate a natural forest. Manitoba Model Forest, Pine Falls, MB.

Elbakidze, M., P. Angelstam and R. Axelsson. 2012. Stakeholder identification and analysis for adaptive governance in the Kovdozersky Model Forest, Russian Federation. The Forestry Chronicle 88(3): 298-305.

[EC and UNDP] European Commission and United Nations Development Programme). 2002. Small Grants Programme. Operations to promote tropical forests in Southeast Asia: Regional Strategic Framework. Los Baños, Philippines.

FAO. 2010. Global forest resources assessment -2010 . Rome.

FAO. 2012. State of Mediterranean Forests (SoMF), concept paper. Rome.

Forestry Canada. 1991. Model Forests: Background information and guidelines for applicants. Ottawa.

Fortin, C., M. Laliberté and J. Ouzilleau. 2002. Management guide for land used by beavers in Quebec. Fondation de la faune du Québec, Sainte-Foy, QC.

Hall, J.E. and B. Bonnell. 2004. Social and collaborative forestry: Canadian Model Forest experience. In J. Burley, J. Evans and J. Youngquist (eds.). Encyclopaedia of forest sciences. pp. 1162-1173. Elsevier, Oxford.

IMFN Secretariat. 2008. Guide to Model Forest Governance. Ottawa.

Jum, C., C. Diaw, J. Nguiebouri and M. Zoa. 2007. Enhancing sustainable forest management in Cameroon through a model forest based approach. International Forestry Review 9(4): 892-900.

Kimmins, J.P. 1995. Sustainable development in Canadian forestry in the face of changing paradigms. The Forestry Chronicle 71(1): 33-40.

Korchumova, S. 2007. Development projects that work: Multidisciplinarity in action. Globalhood Research Paper. Available from http://www.globalhood.org/articles/briefingnotes/Development_Pr ojects_that_work.pdf.

Kurz, W.A., M. Apps, E. Banfield and G. Stinson. 2002. Forest carbon accounting at the operational scale. The Forestry Chronicle 78(5): 672-679.

Kurz, W.A. et al. 2009. CBM-CFS3: A model of carbon-dynamics in forestry and land-use change implementing IPCC standards. Ecological Modelling 220(4): 480-504.

Kushalappa, C.G. and S. Raghavendra. 2012. Community-linked conservation using Devakad (sacred groves) in the Kodagu Model Forest, India. The Forestry Chronicle 88(3): 266-273. 
Landry, M.E., B. Bonnell, F. Carrera, R. de Camino and M. Barriga. 2011. Model Forest experiences in Ibero-America: A 15-year journey. CATIE, Turrialba, Costa Rica.

LaPierre, L. 2002. Canada's Model Forest Program. The Forestry Chronicle 78(5): 613-617.

Lazar, A. 2005. A proud record of leadership in addressing and adapting to climate change. The Forestry Chronicle 81(5): 631-632. Lemprière, T.C., P.Y. Bernier, A.L. Carroll, M.D. Flannigan, R.P. Gilsenan, D.W. McKenney, E.H. Hogg, J.H. Pedlar and D. Blain. 2008. The importance of forest sector adaptation to climate change. Information report NOR-X-416E. Canadian Forest Service, Edmonton, $\mathrm{AB}$.

Lisberg-Jensen, E. 2002. Thesis. Som man ropar i skogen: Moderniteter, makt och mångfald i kampen om Njakafjäll och den svenska skogsbruksdebatten 1970-2000. Lund Studies in Human Ecology 3. Lund University.

Mayers, J. and S. Vermeulen. 2002. Company-community forestry partnerships: From raw deals to mutual gains? An international review with proposals for improving forests, enterprise and livelihoods. Earthprint Limited, Hertfordshire, UK.

M'Hirit, O. 1999. Mediterranean forests: Ecological space and economic and community wealth. Unasylva 197.

[MCPFE] Ministerial Conference on the Protection of Forests in Europe. 2003. Europe's forests in the spotlight. Vienna.

Mitchell, D. 2009. Non-timber forest products: What's happening in Canada's Model Forests? Canadian Model Forest Network, Kemptville, ON.

Moya, J.A.C. L. Quiros and M. Jimenez. 2012. Challenges in the implementation of conservation policies in the Reventazón Model Forest. The Forestry Chronicle 88(3): 261-265.

Nova Forest Alliance. 2002. Contractors and operators best management practices manual. Stewiacke, NS.

[NRCan] Natural Resources Canada. 2006. Canada's Model Forest Program (CMFP - Follow-up and mid-term evaluation (E05002), May 2006. Ottawa.

. 2011. The state of Canada's forests: Annual report 2011. Cat. No. Fo1-6/2011E. Natural Resources Canada, Ottawa.

Price, D.T., D.H. Halliwell, M.J. Apps, W.A. Kurz and S.R. Curry. 1997. Comprehensive assessment of carbon stocks and fluxes in a Boreal Cordilleran forest management unit. Canadian Journal of Forest Research 27(12): 2005-2016.
Rametsteiner, E. 2009. Governance concepts and their application in forest policy initiatives from global to local levels. Small-scale Forestry 8(2): 143-158.

Sandström, P., C. Sandström, J. Svensson, L. Jougda and K. Baer. 2012. Participatory GIS to mitigate conflicts between reindeer husbandry and forestry in Vilhelmina Model Forest, Sweden. The Forestry Chronicle 88(3): 254-260.

Svensson, J., C. Fries and L. Jougda. 2004. Synthesis of the Model Forest concept and its application to Model Forest Vilhelmina and Barents Model Forest Network. Swedish Forest Agency, Report 6.

Svensson, J., P. Sandström, C. Sandström, L. Jougda and K. Baer. 2012. Sustainable landscape management in the Vilhelmina Model Forest, Sweden. The Forestry Chronicle 88(3): 291-297.

Thorpe, H.C., S.C. Thomas, and J.P. Caspersen. 2007. Residualtree growth responses to partial stand harvest in the black spruce (Picea mariana) boreal forest. Canadian Journal of Forest Research 37(9): 1563-1571.

Tiani, A.M., J.G. Tchoko, H. Eboto, J.C. Njomkap, T. Bouki, A. Ndo and M.C. Diaw. 2012. Dynamiques sociales et stratégies féminines dans la Forêt modèle de Campo-Maan, Cameroun. The Forestry Chronicle 88(3): 283-290.

[UNDESA] UN Department of Economic and Social Affairs. 2012. Population and vital statistics report, statistical papers, series A vol. LXIV. New York.

UNEP. 2010. State of biodiversity in Latin America and the Caribbean. Santiago, Chile.

von Mirbach, M. 2000. A user's guide to local level indicators of sustainable forest management: Experiences from the Canadian Model Forest Network. Natural Resources Canada, Ottawa.

Williamson, T.B., S.J. Colombo, P.N. Duinker, P.A., Gray, R.J. Hennessey, D. Houle, M.H. Johnston, A.E. Ogden and D.L. Spittlehouse. 2009. Climate change and Canada's forests: From impacts to adaptation. Sustainable Forest Management Network and Natural Resources Canada, Canadian Forest Service, Northern Forest Centre, Edmonton, AB. 104 p. 